\title{
Production and Marketing of Ginger: A Case Study in Salyan District, Nepal
}

\author{
Shristi Upadhyaya ${ }^{1 *}$, Raj Kumar Adhikari², Lila B. Karki ${ }^{3}$, O.P. Singh ${ }^{1}$
}

\author{
${ }^{1}$ Agriculture and Forestry University, Nepal \\ ${ }^{2}$ United Nations Development Program, Nepal \\ ${ }^{3}$ University of Maryland Eastern Shore, MD, USA \\ *Correspondence: shristiup624@gmail.com
}

\begin{abstract}
Ginger is an important spice crop grown in the mid-hills of Nepal for cash income. 60 ginger producers were sampled using a simple random sampling technique. Primary data collection was done via questionnaire survey as well as via focus group discussion (FGD), key informant interview (KII) and rapid market appraisal (RMA). The collected data was analyzed using MS Excel and SPSS. Average area under ginger cultivation was 0.13 ha. Average cost of production and the productivity of ginger was NRs. 4,20,000/ha and 14.44 ton/ha respectively. The average selling price of fresh ginger was NRs. 29.34 whereas average selling price of dried ginger was NRs. 201.42. The Benefit Cost ratio of ginger production in the study area was 1.53. The major production related problem could be solved by making consulting services and input supplies more reliable and readily available. Development of the market information system may help in decreasing the dependency of farmers on middlemen. Establishment of farmer-run collection and processing centers in strategic levels could be a sustainable way to address various problems related to marketing of ginger in the study area.
\end{abstract}

Keywords—Ginger production, Benefit Cost ratio, Production problem, Marketing problem, Nepal.

\section{INTRODUCTION}

Ginger (Zingiber officinale Rosc.) is one of the valuable spice crops grown extensively in the mid hills of Nepal. It is one of the high value spice crops which can contribute to improve the socioeconomic status of rural people by raising their income (NSCDP, 2007). There are about 107 spices in use all over the world and more than 25 spices are commonly used in Nepal among which ginger and large cardamom have been exported from the country (GRP, 2017). Nepal is the world's fourth largest ginger producer after India, China and Indonesia with a production of approximately 270 thousand tons per year (Zoder, 2017). In Nepal, among the spice crops ginger occupies 1,262 ha area with production of 15650 tons in 2018 (MoAD, 2018). According to the Ministry of Commerce and Supplies (2010), ginger is one of the agriculture products having an export potential identified by Nepal Trade Integration Strategy. Nepalese government and development partners have identified ginger as a high potential sector for export, value addition and income generation. India is a vast and dynamic market for Nepali ginger (ITC, 2007). India accounts for close to $94 \%$ of Nepal's fresh ginger export and six percent of processed ginger (MoAD, 2018). Nepal exported 39581 tons of ginger in 2013 of which the share of fresh ginger was $96 \%$ in total exports and only $4 \%$ in dried form of which $0.02 \%$ was in powdered form (ANSAB, 2015). According to Sharma (2016), with substantial increments in yield, quality and volume, Nepalese Ginger has huge international trading potential. The top five ginger exporting countries in 2015 are China, Netherlands, India, Nepal and Thailand (Zoder, 2017).

Salyan $\left(28^{\circ} 22^{\prime} 31.01^{\prime \prime} \mathrm{N}, 82^{\circ} 09^{\prime} 42.01^{\prime \prime} \mathrm{E}\right)$ is the major ginger producing district of Nepal. It lies in the mid-hill region at an altitude ranging from about 1530 meters above the sea level. The total area under ginger production in Salyan district in 2016/2017 was 2000 ha with a total production of 27564 tons (MoAD, 2018). The physical and biological condition of Salyan district favors the ginger 
production, but lack of technical knowledge during the period of sowing, poor practice of seed production, lack of storage facility, poor practice of cleaning and processing has reduced the quality of Salyan's ginger which affects the trade of ginger abroad. There is no proper way of recording on production costs as well as on profitability. There is farmers' lack of direct contact and access to market and establishment of local traders' is the only point for the transaction of the produce in Salyan District (Khanal, 2018). The objective of this study was to assess the economics of production and marketing status of ginger in Salyan district of Nepal.

\section{MATERIALS AND METHODS}

\section{Selection of study site}

The present study was conducted in two municipalities (Sarada Municipality and Bagchaur Municipality) and one Rural Municipality (Siddhakumakh) of Salyan district. These areas were purposively selected as major ginger cultivated area of Ginger/Turmeric zone under PMAMP project.

\section{Selection of ginger farmers}

Out of 568 ginger producing farmers, 60 farmers $(10.56 \%$ of the total population) were selected as samples for the survey. List of ginger growing farmers were obtained from the Ginger/Turmeric zone office. Altogether 5 traders were selected for an interview from Sharada Municipality. The study was conducted in the month of January, 2019.

\section{Sources of data}

Primary data were collected from ginger growers, traders, wholesalers and retailers. The information was collected through a household survey using an interview schedule. Observation, Focus Group Discussion (FGD), Key Informant Interview (KII) and Rapid Market Appraisal (RMA) were also used to triangulate the data.

The secondary sources of data were various sources like publication from GOs, NGOs, research articles from national and international journals along with the previous studies in the study area.

\section{Data analysis}

Raw data obtained from the field were analyzed to get to a certain conclusion. Both primary and secondary information collected from field surveys and other methods were coded, tabulated and analyzed by using Statistical Package of Social Science (SPSS) and Microsoft Excel. Different variables in this study were used on both quantitative and descriptive analysis.

\section{Marketing margin}

The difference between the farm gate price i.e. price obtained by the producer and retailer's price i.e. price paid by the consumer is known as marketing margin. It was calculated as:

Marketing margin $=$ Retailer's price $\left(\mathrm{P}_{\mathrm{r}}\right)-$ Farm gate price $\left(\mathrm{P}_{\mathrm{f}}\right)$

\section{Producer's share}

Producer's share is the price received by the farmer expressed as a percentage of the retail price, i.e. the price paid by the consumers. It was calculated by the following formula.

$$
\mathrm{P}_{\mathrm{s}} \quad=\left(\mathrm{P}_{\mathrm{f}} / \mathrm{P}_{\mathrm{r}}\right) \times 100
$$

Where,

$$
\begin{array}{ll}
\mathrm{P}_{\mathrm{s}} & =\text { Producers' share } \\
\mathrm{P}_{\mathrm{r}} & =\text { Retailers' price } \\
\mathrm{P}_{\mathrm{f}} & =\text { Producers' price (Farm gate price) }
\end{array}
$$

\section{Gross margin analysis}

Gross margin is the difference between the revenue and cost of goods sold (production cost not including indirect fixed cost like office expenses, rent or administrative costs) for any enterprises. The gross margin of the ginger in this study was calculated as below:

Gross margin $=\frac{\text { Revenue }- \text { cost of good sold }}{\text { Revenue }} \times 100$

If the margin is $\mathrm{x} \%$, then $\mathrm{x} \%$ of sales total is gross profit.

\section{Benefit cost analysis}

Cost benefit analysis was done after calculating the total variable cost and gross return from the ginger cultivation. Cost of production was calculated by summing all the variable cost items in the production process. For calculating gross return, income from product sales was accounted. So, the benefit cost analysis was carried out by using formula:

$\mathrm{B} / \mathrm{C}$ Ratio = Gross return / total variable cost

Where,

Gross return $=$ Total quantity of ginger marketed $(\mathrm{Kg}) \times$ Price per unit of ginger (Rs)

Total variable costs $=$ Summation of all variable cost items 


\section{Marketing channel}

Marketing channels was drawn based on the information obtained from producer level to consumer level. All linkage and coordination among all levels i.e. input supplier, grower, collector, retailer and final consumer were analyzed for the marketing channel.

\section{Problem prioritization}

5-point scale: 1 for most problematic, 0.8 for second most problematic, following the order $0.6,0.4$ and 0.2 for least problematic one

$\mathrm{I}_{\mathrm{imp}}=\Sigma\left(\mathrm{S}_{\mathrm{i}} \mathrm{f}_{\mathrm{i}} / \mathrm{N}\right)$

Where,

$\mathrm{I}_{\mathrm{imp}}=$ Index of importance

$$
\mathrm{S}_{\mathrm{i}}=\mathrm{i}^{\text {th }} \text { scale value }(\mathrm{i}=1,0.8,0.6,0.4,0.2)
$$

$\mathrm{f}_{\mathrm{i}}=$ frequency of $\mathrm{i}^{\text {th }}$ importance given by respondents

$\mathrm{N}=$ total number of respondents

\section{RESULTS AND DISCUSSIONS}

\section{Socio-demographic characteristics of ginger farmers}

The total population of 60 respondent households was found to be 349 with an average family number of 6.58 . The study showed that the average number of male and females in the family was 3.26 and 3.32 respectively. $53 \%$ of the respondents were male whereas $47 \%$ were female. It indicates that males relatively have a lead role in providing information about the household rather than females. The respondents belonged to six different ethnic groups Chhetri(61.67\%), Dalit (13.33\%), Janajati (8.33\%), Sanyasi (8.33\%), Brahmin (5\%) and Thakuri (3.33\%). Respondents were categorized into five education levels i.e. illiterate, primary level, lower secondary level, secondary level and higher studies. $13 \%$ of the respondents have had higher education, $24 \%$ of the respondents were found to have a secondary level of education, $8 \%$ had attended lower secondary school, 9\% had attended primary level, $23 \%$ of them were literate and $19 \%$ of respondents were illiterate. Most of the people (55\%) in this area depend on agriculture for livelihood followed by abroad and agriculture (20\%). Similarly, along with agriculture, $15 \%$ were involved in services and $10 \%$ in business. Age of the family members was categorized into three different groups namely below 15 years, 15 to 59 (economically active population), above 60 years. During the study it was found that the majority of the population $(60.17 \%)$ was in the economically active age group.

\section{Production situation}

The average land holding size of people in this area was 0.80 ha. Among that average land, area under ginger cultivation was 0.13 ha $(16.25 \%$ of average land holding size) with productivity 14.44 ton/ha. In a study done by Mahat (2019); the average productivity of ginger was found to be 22.07 ton/ha which is more than the productivity seen in this study.

Table 1: Production status of Ginger compared to total land area as above

\begin{tabular}{|l|l|l|l|l|}
\hline Description & Minimum & Maximum & Mean & Standard Deviation \\
\hline Total area (ha) & 0.10 & 4.07 & 0.80 & 0.73 \\
\hline Ginger Cultivated area (ha) & 0.02 & 0.61 & 0.13 & 0.10 \\
\hline Ginger production (ton/ha) & 3.17 & 30.87 & 14.44 & 5.93 \\
\hline
\end{tabular}

\section{Cost of production}

The cost of production includes input cost (seed rhizome, fertilizer, manure), labor (land preparation, intercultural operation, post-harvest operation, marketing) and other associated costs. According to the findings, the average cost of production (per hectare) in the study area was NRs. 4,20,000 (USD 1= NRs.110) 
Table 2: Cost of ginger cultivation per hectare

\begin{tabular}{|l|l|l|l|}
\hline S.N. & Description & $\begin{array}{l}\text { Average cost of production per hectare } \\
(\text { NRs. })\end{array}$ & $\begin{array}{l}\text { Contribution to total cost } \\
(\%)\end{array}$ \\
\hline A & Inputs & & \\
\hline 1 & Rhizome & 200,000 & 47.61 \\
\hline 2 & Fertilizer (FYM) & 50,000 & 11.90 \\
\hline 3 & Chemical Fertilizer & 8,575 & 2.04 \\
\hline B & Labor & & 9.52 \\
\hline 1 & Land Preparation & 40,000 & 7.14 \\
\hline 2 & Plantation & 30,000 & 7.14 \\
\hline 3 & Weeding & 30,000 & 9.52 \\
\hline 4 & Harvesting & 40,000 & 5.10 \\
\hline 5 & Transportation & 21,425 & 100 \\
\hline C & Grand Total & 420,000 & \\
\hline D & $\begin{array}{l}\text { Average ginger production per hectare } \\
\text { (ton/ha) }\end{array}$ & 14.44 & \\
\hline E & Cost of Production per kg of Ginger (NRs) & 32.06 & \\
\hline
\end{tabular}

(USD $1=$ NRs. 110)

It was found that the highest cost was incurred for seed rhizome $(47.61 \%)$. Similarly, on similar studies performed by Kumar (2017) and Poudel (2007), cost for seed was reported up to $41.90 \%$ in India and $65.1 \%$ in Palpa district of Nepal respectively. The cost of production per $\mathrm{kg}$ of ginger was NRs. 32.06.

\section{Selling price of ginger}

The finding of the interview with the ginger grower showed that farmer from study sites sold their ginger in different forms i.e. fresh ginger, dried ginger (sutho), seed rhizome, and mother rhizome (Bruni). The price of different forms of ginger is mentioned in the table below (Table 3).

Table 3: Price of different form of ginger (NRs/kg)(USD l= NRs.110)

\begin{tabular}{|l|l|l|l|l|l|}
\hline Forms of Ginger & N & Minimum & Maximum & Mean & Standard Deviation \\
\hline Dried Ginger (Sutho) & 7 & 90 & 250 & 201.42 & 53.67 \\
\hline Seed Rhizome & 12 & 40 & 120 & 80.41 & 24.9 \\
\hline Mother Rhizome & 31 & 30 & 120 & 68.87 & 19.48 \\
\hline Fresh Ginger & 47 & 12 & 45 & 29.34 & 8.52 \\
\hline
\end{tabular}

\section{Quantity of different forms of ginger}

On average, we found that the quantity of dried ginger (sutho) marketed was $2,434.04 \mathrm{~kg} / \mathrm{ha}$. The quantity of mother rhizomes sold was $2,294.72 \mathrm{~kg} / \mathrm{ha}$. Likewise, fresh ginger $5973.20 \mathrm{~kg} / \mathrm{ha}$, seed rhizome $1,961.85 \mathrm{~kg} / \mathrm{ha}$. The rhizome for next year was found to be $4,450.72 \mathrm{~kg} / \mathrm{ha}$. 
Table 4: Quantity of different forms of ginger ( $\mathrm{kg} / \mathrm{ha}$ )

\begin{tabular}{|l|l|l|l|l|l|}
\hline Variables & N & Minimum & Maximum & Mean & Standard Deviation \\
\hline Sutho & 7 & 841.02 & 5,895 & $2,434.04$ & 1831.57 \\
\hline Mother rhizome & 31 & 196.5 & 7,860 & $2,294.72$ & 1402.81 \\
\hline Fresh ginger & 47 & 982.5 & 13,755 & $5,973.20$ & 3430.10 \\
\hline Seed rhizome & 12 & 786 & $2,593.8$ & $1,961.85$ & 1080.75 \\
\hline Rhizome for next year & 60 & 884.25 & 9,825 & $4,450.72$ & 1703.65 \\
\hline
\end{tabular}

\section{Gross income from different forms of ginger}

The gross income from various forms of ginger is given in Table 5. The sum of income from sales of each form of ginger per hectare was calculated for each farmer. Then, an average was calculated from this sum of all the sample population to determine average total income per hectare which was found to be NRs. 646,742.80(USD l=NRs.110)

Table 5: Gross income from different forms of ginger (NRs. /ha)

\begin{tabular}{|l|l|l|l|l|l|}
\hline Forms of Ginger & $\mathbf{N}$ & Minimum & Maximum & Mean & Standard Deviation \\
\hline Sutho & 7 & 176,850 & 491,250 & $330,824.6$ & 122376.9 \\
\hline Mother rhizome & 31 & 15,720 & 550,200 & $160,688.7$ & 115668.5 \\
\hline Fresh ginger & 47 & $20,632.5$ & 550,200 & $169,549.2$ & 111226.9 \\
\hline Seed rhizome & 12 & 62,880 & 314,400 & $164,077.5$ & 79723.98 \\
\hline Rhizome for next year & 60 & $43,947.23$ & 975,426 & $357,894.9$ & 226035.5 \\
\hline
\end{tabular}

\section{Benefit cost ratio of ginger}

Benefit cost analysis shows that farmers were making nearly NRs. 226,742.80 profit or gross return per hectare while cultivating the ginger.

Table 6: Benefit cost ratio of ginger

\begin{tabular}{|l|l|}
\hline Cost of production for 1 ha & NRs. 420,000 \\
\hline Income from 1 ha & NRs. 646,742.80 \\
\hline Profit & NRs. 226,742.80 \\
\hline Benefit Cost ratio (B:C ratio) & $\mathbf{1 . 5 3}$ \\
\hline
\end{tabular}

It was found that the benefit cost ratio for ginger farming (all forms of ginger) was 1.53. Since the Benefit Cost ratio was more than unity, ginger cultivation can be considered as profitable business.

\section{Market Channel}

Ginger marketing includes all the activities involved in the transfer of farmer's product, either fresh or processed, to the consumers at both domestic and international level. Different channels were involved in the transfer of different forms of ginger from farmers to consumers. The type of channel involved varied on the basis of forms of ginger the farmer had and the location where the farm was present. Sutho was mainly sold to the traders in the Indian markets. Generally, almost all the producers sold ginger to the local collectors without any intermediaries. The ginger from Salyan were found to be transported to different domestic markets of Nepal, as well as to the traders in Indian markets operating on commission-basis. The common marketing channel found in the flow of ginger from producers of Salyan is presented in the figure below: 


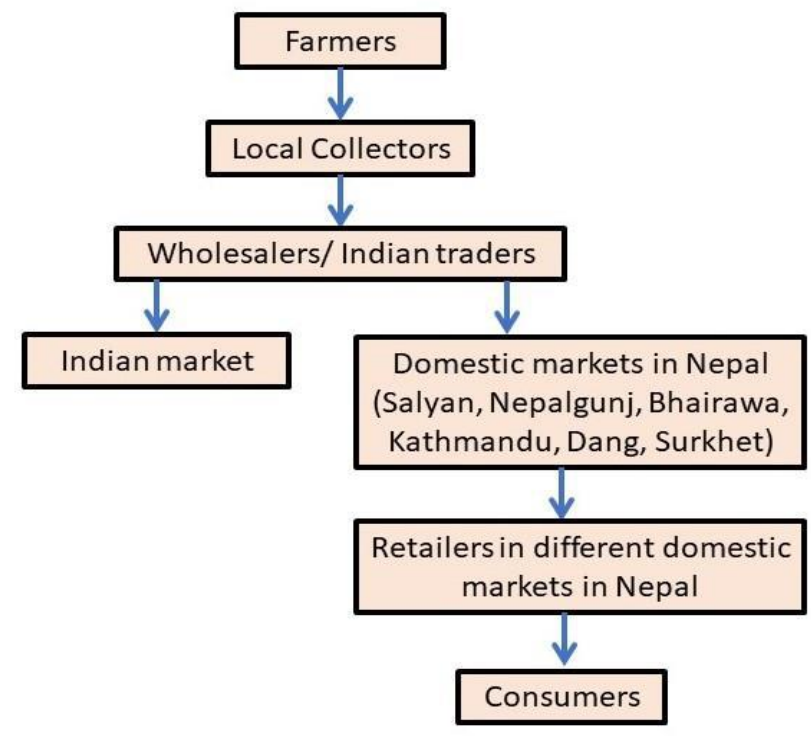

Fig 1: Marketing Channel of Ginger in Salyan District

\section{Market margin and producer share of zone vicinity area}

Market margin and producer share are important determinants for market efficiency. Lower marketing margin and higher producer share on retail price indicates an efficient market system.

Table 7: Market margin and producer share of zone vicinity area (Prices in NRs.)

\begin{tabular}{|l|l|l|l|l|l|}
\hline Forms of Ginger & $\begin{array}{l}\text { Farm gate } \\
\text { price }\left(\mathbf{P}_{\mathbf{f}}\right) \mathbf{p e r} \\
\mathbf{k g}\end{array}$ & $\begin{array}{l}\text { Retailer's } \\
\text { price }\left(\mathbf{P}_{\mathbf{r}}\right) \text { per } \\
\mathbf{k g}\end{array}$ & $\begin{array}{l}\text { Market } \\
\text { margin } \\
\left(\mathbf{M}_{\mathbf{m}}\right)\end{array}$ & $\begin{array}{l}\text { Market } \\
\text { margin } \\
(\boldsymbol{\%})\end{array}$ & $\begin{array}{l}\text { Producer's share } \\
\left(\mathbf{P}_{\mathbf{s}}\right)(\boldsymbol{\%})\end{array}$ \\
\hline Fresh ginger & 29.34 & 55 & 25.66 & 46.65 & 53.34 \\
\hline Dried ginger & 201.42 & 270 & 68.58 & 25.4 & 74.6 \\
\hline Mother rhizome & 68.87 & 90 & 21.13 & 23.47 & 76.52 \\
\hline Seed rhizome & 80.41 & 110 & 29.59 & 26.9 & 73.1 \\
\hline
\end{tabular}

The study revealed that the average price received by the farmers i.e. the farm gate price for fresh ginger was NRs. $29.34 / \mathrm{kg}$ and the price paid by the consumer i.e. the retailer's price was NRs. $55 / \mathrm{kg}$ with a market margin of NRs. 25 and producer's share of $53.34 \%$. Calculated average price received by the farmer was only NRs. $29.34 / \mathrm{kg}$ which was less than the cost incurred for producing one $\mathrm{kg}$ ginger i.e. NRs. 32.06. Price of ginger depends entirely on demand in India and the whims of the Nepal-India border because of which the price of ginger is not stable and greater fluctuation is seen even within a year.
Dried ginger (sutho) is the major value-added product of ginger which is made from fresh mature rhizome by drying, so that it can be preserved for a longer period of time. Dried ginger required high labor cost for cleaning, drying and processing therefore, producers only prepared sutho if the market price for fresh ginger is comparatively low. Around 6 quintal fresh ginger is required to produce 1 quintal dried ginger (6:1 fresh ginger to dried ginger) so the price of dried ginger was high. The study revealed that the farm gate price for dried ginger and retailer's price was NRs. 201.42 and NRs. 270 respectively with a market margin of NRs. 68.58 and a producer share of $74.6 \%$. The average farm gate price 
of sutho was less than the cost incurred for producing $1 \mathrm{~kg}$ of sutho (NRs. 224.56).

Harvesting of mother rhizomes was done 3-4 months after the plantation of ginger. Generally, growers harvested mother rhizomes when there was high demand in the market because at that time the price of the ginger was higher than at the main season of harvest. The study revealed that the average price received by the farmers from mother rhizome was NRs. $68.67 / \mathrm{kg}$ and the price paid by the consumer for 1 $\mathrm{kg}$ of mother rhizome (Retailer's price) was NRs. 90 with a market margin of NRs. 21.13 and the highest percentage of producer's share i.e. $76.52 \%$.

Majority of the farmers used locally available variety from their own production as planting materials which they preserved in the soil pit. A few farmers purchased seed from the neighbors. During the study, it was found that the farm gate price for seed rhizomes was NRs. 80.41. The price paid by the consumer's i.e. retailer's price was NRs. 110 with a market margin of NRs. 29.59. Producer's share for seed rhizome was found to be $73.1 \%$.

\section{Production and Market problems}

Each of the problems were given a weightage from 1 to 5 and then obtained frequencies were multiplied with the respective weightage. The obtained results were then added and then divided with the total number of respondents i.e. 60 multiplied by the highest weightage value i.e. 5 and then index value was obtained. The ranks were assigned in accordance with the obtained index value.

Table 8: Problems in ginger production as ranked by ginger producers in study area

\begin{tabular}{|l|l|l|l|l|l|l|l|l|l|l|l|}
\hline S.N. & Problems & \multicolumn{4}{|l|}{ Frequency } & Total & Weightage & Index & Rank \\
\hline & & P1 & P2 & P3 & P4 & P5 & & & & & \\
\hline 1 & Rhizome rot & 48 & 9 & 2 & 0 & 1 & 60 & 56.6 & 0.943333 & I \\
\hline 2 & Dry rot & 5 & 28 & 19 & 4 & 4 & 60 & 41.2 & 0.686667 & II \\
\hline 3 & Availability of quality rhizome & 5 & 19 & 19 & 6 & 11 & 60 & 36.2 & 0.603333 & III \\
\hline 4 & Post-harvest loss & 3 & 2 & 8 & 30 & 17 & 60 & 24.8 & 0.413333 & IV \\
\hline 5 & Input availability & 1 & 3 & 11 & 19 & 26 & 60 & 22.8 & 0.38 & V \\
\hline
\end{tabular}

Where, $\mathrm{P}=$ Priority level.

All 60 ginger producers were asked to rank the problems in ginger production as listed in the interview schedule. According to the priority ranking of the producers "Rhizome rot" was found to be most problematic while "Input availability" was ranked least problematic.

\section{Marketing problems of ginger}

Each of the problems were given a weightage from 1-5 and then obtained frequencies were multiplied with the respective weightage. The obtained results were then added and then divided with the total number of respondents i.e. 60 multiplied by the highest weightage value i.e. 5 and then index value was obtained. The ranks were assigned in accordance with the obtained index value.

Table 9: Marketing problems as ranked by ginger producers in the study area as above

\begin{tabular}{|l|l|l|l|l|l|l|l|l|l|l|l|}
\hline S.N. & Problems & \multicolumn{4}{|l|}{ Frequency } & Total & Weightage & Index & Rank \\
\hline & & P1 & P2 & P3 & P4 & P5 & & & & \\
\hline 1 & Low market price of Ginger & 11 & 26 & 12 & 10 & 1 & 60 & 60.8 & 1.013333 & I \\
\hline 2 & Lack of storage facilities & 36 & 13 & 7 & 4 & 0 & 60 & 52.2 & 0.87 & II \\
\hline 3 & Lack of Transportation & 5 & 10 & 14 & 17 & 14 & 60 & 31 & 0.516667 & III \\
\hline
\end{tabular}




\begin{tabular}{|l|l|l|l|l|l|l|l|l|l|l|}
\hline 4 & Lack of processing facilities & 4 & 8 & 16 & 15 & 17 & 60 & 29.4 & 0.49 & IV \\
\hline 5 & Quality issue & 4 & 3 & 11 & 14 & 28 & 60 & 24.2 & 0.403333 & V \\
\hline
\end{tabular}

Where, $\mathrm{P}=$ Priority level.

The five different market problems were listed in the interview schedule and 60 ginger producers were asked to rank the problems in accordance with their perception. The first problem as ranked by the producers was "Low market price of ginger" followed by "Lack of storage facilities" and the "Quality issue" was ranked last indicating consumers preferred the prevailing quality of ginger.

\section{CONCLUSION}

The climatic and geographic suitability of Salyan provides an ample opportunity to the farmers to grow ginger. Despite the opportunities, there was predominance of traditional practices in cultivation and processing of ginger prevailing in the district. Dried ginger (sutho) was the major value-added product and it was prepared in a very few households also in fewer quantities. Rhizome rot and low market price of fresh ginger were the major pressing constraints for production and marketing of ginger in the area respectively. Because there was no direct linkage of roads in major ginger growing areas, the farmers were compelled to sell their produce to the local traders and were minimally paid. Despite many problems, the ginger production in the study area was a profitable business (Benefit Cost ratio of 1.53) and gross margin was NRs. 226,742.80/ha. The cost of production per $\mathrm{kg}$ of ginger was NRs. 32.06 but the average selling price of fresh ginger was NRs. 29.34/kg. Farmers were not getting a fair price for fresh ginger. However, if the alternative approach is followed i.e. harvesting ginger in multiple forms (mother rhizome, sutho, seed rhizome), they will easily access the market, which may be more profitable than solely selling it in fresh form. In addition, the farmers do not account farm labor while calculating the cost of production. Due to this reason, even though the farmers think their enterprise as profitable, it actually is not. When labor cost was accounted, sales of ginger in the present price range would cause loss to the farmers. So, the farmers should be suggested to calculate the farm gate price of ginger by considering labor cost as well. The government should intervene in the pricing of ginger by either through subsidies to the farmers or by helping farmers to get a fair price for their product.

\section{ACKNOWLEDGEMENTS}

The authors acknowledge Agriculture and Forestry University, Rampur, Chitwan, Nepal and Ginger Zone Implementation Unit, Salyan of Prime Minister Agriculture Modernization Project for providing the support and Nepalese Agricultural Professionals of Americas (NAPA) for funding the project. The authors would also like to acknowledge the valuable support provided by Mr. Biplov Sapkota in the preparation of the manuscript.

\section{REFERENCES}

[1] Asia Network for Sustainable Agriculture and Bioresources. (2015). A market study for Nepalese ginger and its derivatives in India and Bangladesh markets.

[2] Ginger Research Program. (2017). NARC Annual Report. Kapurkot, Salyan, Nepal.

[3] International Trade Center. (2007). Export Potential Assessment in Nepal.

[4] Khanal, K. (2018). Factors Affecting and Marketing Chain of Ginger in Salyan District, Nepal. Int. J. Appl. Sci. Biotechnol, 6(2). https://doi.org/10.3126/ijasbt.v6i2.xxxxx

[5] Kumar, D. (2017). Cost and return of ginger in Bidar district of Karnataka an economic analysis. Journal of Pharmacognosy and Phytochemistry, 6(5), 472-475.

[6] Mahat, S., Sapkota, S., Sapkota, S., \& Katuwal, K. (2019). Factors Affecting Ginger Production in Surkhet District, Nepal. International Journal of Applied Sciences and Biotechnology, 7(2), 269-273. https://doi.org/10.3126/ijasbt.v7i2.24650

[7] Ministry of Agricultural Development. (2018). Statistical Information on Nepalese Agriculture (2073/74).

[8] Ministry of Commerce and Supplies, G. of N. (2010). Executive summary and action matrix.

[9] National Spice Crops Development Program. (2007). An Annual Report for 2007. Khumaltar, lalitpur.

[10] Poudel, D. (2007). The trade scenario of Spice Crops of Nepal. In Annual report of National Spice Crops Development Program. Lalitpur, Nepal.

[11] Sharma, B. P. A. (2016). Nepal Ginger Profile 2016 Research Report: An Assessment of Commercial Ginger Cultivated in Nepal.

[12] Zoder, L. S. (2017). Ginger Sector in Nepal. GIZ Nepal. 